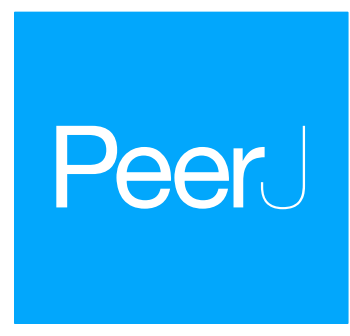

Submitted 14 February 2018 Accepted 20 July 2018

Published 17 September 2018

Corresponding author

Chian-Ren Jeng, crjeng@ntu.edu.tw

Academic editor

Susanne Brander

Additional Information and Declarations can be found on page 16

DOI 10.7717/peerj.5432

Copyright

$2018 \mathrm{Li}$ et al.

Distributed under

Creative Commons CC-BY 4.0

\section{Th2 cytokine bias induced by silver nanoparticles in peripheral blood mononuclear cells of common bottlenose dolphins (Tursiops truncatus)}

\author{
Wen-Ta Li ${ }^{1,2}$, Lei-Ya Wang ${ }^{1,2}$, Hui-Wen Chang ${ }^{1,2}$, Wei-Cheng Yang ${ }^{2}$, Chieh Lo $^{3}$, \\ Victor Fei Pang ${ }^{1,2}$, Meng-Hsien Chen ${ }^{4}$ and Chian-Ren Jeng ${ }^{1,2}$ \\ ${ }^{1}$ Graduate Institute of Molecular and Comparative Pathobiology, National Taiwan University, Taipei, Taiwan \\ ${ }^{2}$ School of Veterinary Medicine, National Taiwan University, Taipei, Taiwan \\ ${ }^{3}$ Farglory Ocean Park, Hualien, Taiwan \\ ${ }^{4}$ Department of Oceanography and Asia-Pacific Ocean Research Center, National Sun Yat-Sen University, \\ Kaohsiung, Taiwan
}

\section{ABSTRACT}

Background. Silver nanoparticles (AgNPs) have been widely used in many commercial products due to their excellent antibacterial ability. The AgNPs are released into the environment, gradually accumulate in the ocean, and may affect animals at high trophic levels, such as cetaceans and humans, via the food chain. Hence, the negative health impacts caused by AgNPs in cetaceans are of concern. Cytokines play a major role in the modulation of immune system and can be classified into two types: Th1 and Th2. Th1/Th2 balance can be evaluated by the ratios of their polarizing cytokines (i.e., interferon [IFN]- $\gamma /$ Interleukin [IL]-4), and animals with imbalanced Th1/Th2 response may become more susceptible to certain kinds of infection. Therefore, the present study evaluated the in vitro cytokine responses of cetacean peripheral blood mononuclear cells (cPBMCs) to $20 \mathrm{~nm}$ citrate-AgNPs $\left(\mathrm{C}-\mathrm{AgNP}_{20}\right)$ by quantitative reverse transcriptase polymerase chain reaction (qRT-PCR).

Methods. Blood samples were collected from six captive common bottlenose dolphins (Tursiops truncatus). The cPBMCs were isolated and utilized for evaluating the in vitro cytokine responses. The cytokines evaluated included IL-2, IL-4, IL-10, IL-12, interferon (IFN)- $\gamma$, and tumor necrosis factor (TNF)- $\alpha$. The geometric means of two housekeeping genes (HKGs), glyceraldehyde 3-phosphate dehydrogenase (GAPDH) and $\beta 2$-microglobulin (B2M), of each sample were determined and used to normalize the mRNA expression levels of target genes.

Results. The ratio of late apoptotic/necrotic cells of cPBMCs significantly increased with or without concanavalin A (ConA) stimulation after $24 \mathrm{~h}$ of $10 \mu \mathrm{g} / \mathrm{ml} \mathrm{C}-\mathrm{AgNP}_{20}$ treatment. At $4 \mathrm{~h}$ of culture, the mRNA expression level of IL-10 was significantly decreased with $1 \mu \mathrm{g} / \mathrm{ml} \mathrm{C}-\mathrm{AgNP}_{20}$ treatment. At $24 \mathrm{~h}$ of culture with $1 \mu \mathrm{g} / \mathrm{ml} \mathrm{C}$ $\mathrm{AgNP}_{20}$, the mRNA expression levels of all cytokines were significantly decreased, with the exceptions of IL- 4 and IL-10. The IFN- $\gamma /$ IL- 4 ratio was significantly decreased at 24

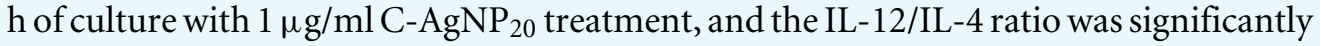
decreased at 4 or $24 \mathrm{~h}$ of culture with 0.1 or $1 \mu \mathrm{g} / \mathrm{ml} \mathrm{C-AgNP} 20$ treatment, respectively. Furthermore, the mRNA expression level of TNF- $\alpha$ was significantly decreased by $1 \mu \mathrm{g} / \mathrm{ml} \mathrm{C}-\mathrm{AgNP}_{20}$ after $24 \mathrm{~h}$ of culture. 
Discussion. The present study demonstrated that the sublethal dose of C-AgNP20 $(\leq 1 \mu \mathrm{g} / \mathrm{ml})$ had an inhibitory effect on the cytokine mRNA expression levels of cPBMCs with the evidence of Th2 cytokine bias and significantly decreased the mRNA expression level of TNF- $\alpha$. Th2 cytokine bias is associated with enhanced immunity against parasites but decreased immunity to intracellular microorganisms. TNF- $\alpha$ is a contributing factor for the inflammatory response against the infection of intracellular pathogens. In summary, our data indicate that $\mathrm{C}-\mathrm{AgNP}_{20}$ suppresses the cellular immune response and thereby increases the susceptibility of cetaceans to infection by intracellular microorganisms.

Subjects Toxicology, Veterinary Medicine, Immunology, Ecotoxicology, Environmental Contamination and Remediation

Keywords Cetacean, Silver nanoparticles (AgNPs), Immunotoxicity, Cytokine, Th2 bias, qRT-PCR

\section{INTRODUCTION}

The application of silver nanoparticles (AgNPs) in industry and in consumer products has increased, and the production of AgNPs and the number of AgNP-containing products will increase over time (Massarsky, Trudeau \& Moon, 2014). AgNPs can be released during the production, transport, decay, use, and/or disposal of AgNP-containing products, subsequently draining into the surface water and then accumulating in the marine environment (Farre et al., 2009; Walters, Pool \& Somerset, 2014). Therefore, the increasing use and growing production of AgNPs, as potential sources of Ag contamination, raise public concerns about the environmental toxicity of Ag ( Li et al., 2018a). Previous research has demonstrated that AgNPs can precipitate in marine sediments, be ingested by benthic organisms (such as benthic invertebrate species), enter and be transferred from one trophic level to the next via the food chain, and thereby cause negative effects on the animals at different trophic levels, such as algae, invertebrates and fishes (Buffet et al., 2014; Farre et al., 2009; Gambardella et al., 2015; Huang, Cheng \& Yi, 2016b; Wang et al., 2014). Previous studies have demonstrated that AgNPs are toxic to all tested marine organisms in a dosedependent manner, indicating that AgNPs may have negative effects on marine organisms at different trophic levels of the marine environment. Immunotoxic effects of AgNPs have been demonstrated in some aquatic animals such as Nile tilapia and mussel (Gagne et al., 2013; Thummabancha, Onparn \& Srisapoome, 2016). Nevertheless, to date the potential toxicity of AgNPs on marine mammals such as cetaceans has not been sufficiently studied.

AgNPs have been demonstrated to cause several negative effects, such as hepatitis, nephritis, neuron cell apoptosis, and alteration of gene expression of the brain, on laboratory mammals (Espinosa-Cristobal et al., 2013; Sardari et al., 2012; Shahare \& Yashpal, 2013). In vitro studies using different cell lines have also indicated that AgNPs can cause damage to DNA, cell membranes, and mitochondria through reactive oxygen species (ROS) dependent/independent pathways and further induce cytotoxicity and genotoxicity (Kim \& Ryu, 2013). In addition, previous studies conducted in laboratory mammals, including mice and rats, have demonstrated that AgNPs can enter the blood circulation through 
alimentary tracts and then deposit in multiple organs (Espinosa-Cristobal et al., 2013; Lee et al., 2013; Shahare \& Yashpal, 2013; Van der Zande et al., 2012). Considering the negative effects of AgNPs and the presence of AgNPs in blood circulation, the negative effects of AgNPs on leukocytes should be of concern. Previous studies have demonstrated that AgNPs can cause several negative effects on human polymorphonuclear leukocytes (PMNs) and peripheral blood mononuclear cells (PBMCs). These studies demonstrated that AgNPs can cause morphological alterations, cytotoxicity, atypical cell death, inhibition of de novo protein synthesis, increased production of the CXCL8 chemokine (IL-8), and impaired lysosomal activity in human neutrophils (Poirier et al., 2014; Poirier, Simard \& Girard, 2016; Soares et al., 2016). Only a few studies have investigated the toxicity of AgNPs on human PBMCs, which have shown that AgNPs can cause cytotoxicity and functional perturbations, including inhibition of proliferative activity and cytokine production (Franco-Molina et al., 2016; Ghosh et al., 2012; Huang et al., 2016a; Orta-Garcia et al., 2015; Paino \& Zucolotto, 2015; Shin et al., 2007).

The environmental contamination level of AgNPs is expected to increase greatly in the near future, and cetaceans, as the top predators in the ocean, will suffer the potentially negative impacts caused by AgNPs. Besides, immunotoxic effects of AgNPs have been demonstrated previously in humans and aquatic animals. Therefore, it is crucial to investigate the immunotoxic effects caused by AgNPs in cetaceans. Generally, in vivo experiments are rarely feasible, and the ethical issues concerning the study of immunotoxic effects caused by environmental contaminants in cetaceans are difficult to overcome, so in vitro study using blood samples from captive cetaceans would be a logical and crucial approach (Beineke et al., 2010; Desforges et al., 2016). Cytokines play a major role in the modulation of the immune system, including lymphocyte proliferation/differentiation, lymphoid development, cell trafficking, and inflammatory response through the interactions between the cytokines themselves and the surface receptors of many different cells (Owen et al., 2013; Tizard, 2013a). Previous studies have found that the sequence homology of cytokines among terrestrial and aquatic mammals is low, but conserved molecule regions can still be found on biologically active areas in marine mammals, such as the receptor binding sites of cytokines, suggesting a conserved biological activity of cytokines in both terrestrial and aquatic mammal species (Beineke et al., 2004; Beineke et al., 2010). Therefore, the functions of cytokines on the immune system in cetaceans may be similar to those in mice and humans. Cytokines can be classified into two groups, Th1 and Th2, and their secretion pattern is associated with the balance of Th1 and Th2 responses (Kidd, 2003; Owen et al., 2013; Tizard, 2013b). Th1 response promotes cell-mediated immune response and thus enhances the immunity against intracellular microorganisms, such as Toxoplasma gondii and Brucella spp., and a variety of viruses. In contrast, Th2 response is associated with enhanced immunity against parasites but decreased immunity to intracellular microorganisms (Owen et al., 2013; Tizard, 2013b). The Th1/Th2 balance can be evaluated by the ratios of their polarizing cytokines (i.e., interferon [IFN]- $\gamma /$ interleukin [IL]-4), and animals with imbalanced Th1/Th2 response (Th1/Th2 polarization) may become more susceptible to certain kinds of infection (Owen et al., 2013; Raphael et al., 2015; Tizard, 2013b). 
Table 1 The size distribution and zeta potential of the $20 \mathrm{~nm}$ citrate-AgNPs $\left(\mathrm{C}-\mathrm{AgNP}_{20}\right)$.

\begin{tabular}{lll} 
Concentration $(\boldsymbol{\mu g} / \mathbf{m l})$ & $\mathbf{1 0 0}$ & $\mathbf{5 0 0}$ \\
\hline Z-Average $(\mathrm{nm})$ & $26.62 \pm 0.15$ & $26.54 \pm 0.08$ \\
Size $(\mathrm{nm})($ intensity $)$ & $30.27 \pm 0.18(100 \%)$ & $29.64 \pm 0.30(100 \%)$ \\
Zeta potential $(\mathrm{mV})$ & $-38.97 \pm 1.33$ & $-44.2 \pm 1.35$ \\
PdI & $0.12 \pm 0.00$ & $0.11 \pm 0.01$ \\
\hline
\end{tabular}

Notes.

Results shown are means \pm SD from three different lectures.

NP were suspended in $2 \mathrm{nM}$ citrate buffer and measurements performed at room temperature.

PdI, Poly-dispersity Index.

Cytokine profiling is still a relatively new field of immunotoxicology in cetaceans, and thus the enzyme-linked immunosorbent assay (ELISA) kit is not widely used for cytokine profiling in cetaceans (Desforges et al., 2016). Hence, it is more feasible to study the cytokine profiling by molecular biology (i.e., quantitative reverse transcriptase polymerase chain reaction; qRT-PCR). Therefore, the present study evaluates the in vitro cytokine responses of cPBMCs to $\mathrm{C}-\mathrm{AgNP}_{20}$ by qRT-PCR. The cytokines measured were as follows: polarizing cytokines of Th1 (IL-12 and IFN- $\gamma$ ) and Th2 (IL-4), and some pro- and anti-inflammatory cytokines (IL-2, IL-10, and tumor necrosis factor [TNF]- $\alpha$ ).

\section{MATERIAL AND METHODS}

\section{AgNPs characterization}

Considering the extensive use of $20 \mathrm{~nm}$ citrate-AgNPs $\left(\mathrm{C}-\mathrm{AgNP}_{20}\right)$ in recently reported studies of cetacean and human blood cells (Huang et al., 2016a; Li et al., 2018b; Poirier et al., 2014; Poirier, Simard \& Girard, 2016), commercial C-AgNP 20 (Pelco ${ }^{\circledR}$ citrate Biopure $^{\mathrm{TM}}$ silver; Ted Pella, Redding, CA, USA) was chosen. The C-AgNP 20 had been extensively washed (without centrifugation) so that the level of trace elements becomes less than $0.000001 \%$. Transmission electron microscopy (TEM) for determining surface area and size/shape distributions, UV-visible spectroscopy for measuring the optical properties, particle hydrodynamic diameter and zeta potential, and dynamic light scattering (DLS) for determining the size distribution were performed according to the manufacturer's instructions and previous studies (Poirier et al., 2014; Poirier, Simard \& Girard, 2016). The endotoxin level of C-AgNP 20 suspension was examined by ToxinSensor ${ }^{\mathrm{TM}}$ Single Test Kit (GenScript, Piscataway, NJ, USA), and it was lower than or equal to $0.015 \mathrm{EU} / \mathrm{ml}$. For characterization, the $\mathrm{C}-\mathrm{AgNP}_{20}$ obtained from the manufacturer were suspended in complete RPMI-1640 medium (RPMI-1640 (Gibco, New York, NY, USA) with 10\% fetal bovine serum, $2 \mathrm{mM}$ L-glutamine, $50 \mathrm{IU}$ penicillin, and $50 \mu \mathrm{g}$ streptomycin) at a concentration of $50 \mu \mathrm{g} / \mathrm{ml}$, and then examined using a JEM-1400 (JEOL, Tokyo, Japan) TEM. The size distribution and zeta potential of the $\mathrm{C}-\mathrm{AgNP}_{20}$ were determined through Zetasizer Nano-ZS (Malvern Instruments Inc., Westborough, MA, USA) (Table 1). Measurements were performed by using 100 and $500 \mu \mathrm{g} / \mathrm{ml} \mathrm{C-AgNP}{ }_{20}$ in two $\mathrm{mM}$ citrate buffer ( $\mathrm{pH}$ 7.4). The $\mathrm{C}-\mathrm{AgNP}_{20}$ were diluted to one, 10 , and $100 \mu \mathrm{g} / \mathrm{ml}$ with two $\mathrm{mM}$ citrate buffer and instantly used for subsequent experiments. Two $\mathrm{mM}$ citrate buffer was used as a vehicle control $\left(0 \mu \mathrm{g} / \mathrm{ml} \mathrm{C}-\mathrm{AgNP}_{20}\right)$. 


\section{Animals and blood sample collection}

All procedures involving animals were conducted in accordance with international guidelines, and the protocol has been reviewed and approved by the Council of Agriculture of Taiwan (Approval number 1051700175). Voluntary blood samples were obtained from six clinically healthy bottlenose dolphins (Tursiops truncatus) with confirmation by physical examination, complete blood count, and biochemistry on a monthly basis from 2015 to 2017 at Farglory Ocean Park. Forty millilitres of heparin-anticoagulated whole blood were collected, stored, and shipped at four ${ }^{\circ} \mathrm{C}$ within $8 \mathrm{~h}$ for subsequent experiments.

\section{Isolation of cPBMCs}

Cetacean peripheral blood leukocytes (cPBLs) were collected by slow spin method with minor modifications (Bossart et al., 2008). The isolated cPBLs were resuspended in RPMI1640 (Gibco, New York, NY, USA) with 10\% ethylenediaminetetraacetic acid (EDTA) and subsequently used in the isolation of cPBMCs by density gradient centrifugation method. After centrifugation at $1,200 \times \mathrm{g}$ for $30 \mathrm{~min}$ at $20^{\circ} \mathrm{C}$, the cPBMCs were collected from the cell layer between the RPMI-1640 (Gibco) and Ficoll-Paque PLUS (GE Healthcare, Uppsala, Sweden), washed with RPMI-1640 twice, resuspended to a final concentration of $1 \times 10^{7}$ cells $/ \mathrm{ml}$ in complete RPMI-1640 media, and kept on ice until they were utilized in subsequent experiments. The cell viability of cPBMCs was determined by the trypan blue exclusion method using a hemacytometer, and the cell purity based on the cell size (forward-scattered light; FSC) and inner complexity (side-scattered light; SSC) of cPBMCs were determined by FACScalibur flow cytometry (BD, CA, USA). The cPBMCs with higher than $90 \%$ viability and $80 \%$ purity were used in this study.

\section{Determination of the sub-lethal dose of $\mathrm{C}-\mathrm{AgNP}_{20}$ on $\mathrm{CPBMCs}$ with/without concanavalin A (ConA)}

The cytotoxicity of C-AgNP 20 on cPBMCs was evaluated by the Annexin V-FITC/PI Apoptosis Detection Kit (Strong Biotech, Taipei, Taiwan) according to the manufacturer's instructions. Freshly-isolated cPBMCs were seeded in 96 -well plates at a density of $5 \times 10^{5}$ cells/well and exposed to C-AgNP 20 at concentrations of $0,0.1,1.0$ and $10 \mu \mathrm{g} / \mathrm{ml}$ with or without two $\mu \mathrm{g} / \mathrm{ml}$ ConA (Sigma-Alderich, St. Louis, MO, USA). After $24 \mathrm{~h}$ of culture, cells were collected and resuspended in binding buffer for further analysis by FACScalibur flow cytometry (BD). The percentages of early apoptotic (PI-and Annexin $+)$ and late apoptotic/necrotic cells (PI + and Annexin + ) were determined. A total of 8,000 events/sample were acquired. The sub-lethal doses of $\mathrm{C}-\mathrm{AgNP}_{20}$ for $\mathrm{cPBMCs}$ were determined and subsequently used in the cytokine expression assay.

\section{qRT-PCR efficiency of each primer sets}

The primer sets used in cytokine expression assay are summarized in Table 2. The amplification efficiency (E) of qRT-PCR with each primer set was evaluated by the slope and $R^{2}$ of standard curves using the equation: $E=10^{- \text {(1/slope) }}-1$ (Svec et al., 2015). The standard templates for qRT-PCR with target primer sets were prepared by serial dilution of PCR products, which were amplified from cDNA samples of isolated cPBMCs with target primer sets. The PCR product was 500-fold diluted with subsequent six steps of serial 


\begin{tabular}{|c|c|c|c|c|c|}
\hline Gene & $\begin{array}{l}\text { Accession } \\
\text { number }\end{array}$ & Primer sequence $\left(5^{\prime}-3^{\prime}\right)$ & $\begin{array}{l}\text { Efficiency } \\
(\%)\end{array}$ & $R^{2}$ & Reference \\
\hline \multirow{2}{*}{ GAPDH } & \multirow{2}{*}{ DQ404538.1 } & CACCTCAAGATCGTCAGCAA & \multirow{2}{*}{100.97} & \multirow{2}{*}{0.9949} & \multirow{2}{*}{ Chen et al. (2015) } \\
\hline & & GCCGAAGTGGTCATGGAT & & & \\
\hline \multirow{2}{*}{$\mathrm{B} 2 \mathrm{M}$} & \multirow{2}{*}{ DQ404542.1 } & GGTGGAGCAATCAGACCTGT & \multirow{2}{*}{93.32} & \multirow{2}{*}{0.9984} & \multirow{2}{*}{ Chen et al. (2015) } \\
\hline & & GCGTTGGGAGTGAACTCAG & & & \\
\hline \multirow{2}{*}{ IL-2 } & \multirow{2}{*}{ EU638316 } & CATGCCCAAGAAGGCTACAGAATTG & \multirow{2}{*}{91.92} & \multirow{2}{*}{0.999} & \multirow{2}{*}{ Sitt et al. (2008) } \\
\hline & & GTGAATCTTGTTTCAGATCCCTTTAG & & & \\
\hline \multirow{2}{*}{ IL-4 } & \multirow{2}{*}{ EU-638315 } & GGAGCTGCCTGTAGAAGACGTCTTTGC & \multirow{2}{*}{99.25} & \multirow{2}{*}{0.9982} & \multirow{2}{*}{ Sitt et al. (2008) } \\
\hline & & CTTCATTCACAGAACAGGTCATGTTTGCC & & & \\
\hline \multirow{2}{*}{ IL-10 } & \multirow{2}{*}{ AB775207 } & TGCTGGAGGACTTTAAGGGTTA & \multirow{2}{*}{93.14} & \multirow{2}{*}{0.9986} & \multirow{2}{*}{ Segawa et al. (2013) } \\
\hline & & ATGAAGATGTCAAACTCACTCATG & & & \\
\hline \multirow{2}{*}{ IL-12 } & \multirow{2}{*}{ EU638319 } & CAGACCAGAGCGATGAGGTCTTG & \multirow{2}{*}{91.08} & \multirow{2}{*}{0.9999} & \multirow{2}{*}{ Sitt et al. (2008) } \\
\hline & & GGGCTCTTTCTGGTCCTTTAAGATA & & & \\
\hline \multirow{2}{*}{ IFN- $\gamma$} & \multirow{2}{*}{ EU638318 } & CAGAGCCAAATAGTCTCCTTCTACTTC & \multirow{2}{*}{92.42} & \multirow{2}{*}{0.9976} & \multirow{2}{*}{ Sitt et al. (2008) } \\
\hline & & CTGGATCTGCAGATCATCTACCGGAATTTG & & & \\
\hline \multirow{2}{*}{ TNF- $\alpha$} & \multirow{2}{*}{ EU638323 } & GAGGGAAGAGTTCCCAACTGGCTA & \multirow{2}{*}{101.48} & 0.9934 & Sittet al (2008) \\
\hline & & CTGAGTACTGAGGTTGGCTACAAC & & 0.9934 & Stit et al. (2008) \\
\hline
\end{tabular}

10-fold dilutions, and subsequently used for qRT-PCR. The Cycle threshold (Ct) values of each dilution were evaluated by qRT-PCR with each primer set to generate the standard curves.

\section{Extraction of RNA, synthesis of CDNA and qRT-PCR}

Total RNA was extracted from blood samples by RNeasy ${ }^{\circledR}$ Mini Kit (Qiagen, Valencia, CA, USA) according to the manufacturer's instructions. The RNA samples were treated with genomic DNA (gDNA) wipeout solution (Qiagen). Treated samples were then tested by qRT-PCR to confirm the absence of residue gDNA prior to cDNA synthesis. The QuantiTect ${ }^{\circledR}$ Reverse Transcription kit (Qiagen) was used for cDNA synthesis. The reverse transcription was conducted within $4 \mathrm{~h}$ after RNA extraction. The cDNA from each sample was stored at $-20{ }^{\circ} \mathrm{C}$ for qRT-PCR. The qRT-PCR was performed on Mastercycler ${ }^{\circledR}$ ep realplex (Eppendorf, Hamburg, Germany). Each reaction contained 10 $\mu \mathrm{l}$ of SYBR ${ }^{\circledR}$ Advantage ${ }^{\circledR}$ qPCR Premix (Clontech, Mountain View, CA, USA), $7.2 \mu l$ of RNase/DNase-free sterile water, $0.4 \mu \mathrm{l}$ of each $10 \mathrm{mM}$ forward/reverse primers, and two $\mu \mathrm{l}$ of DNA template, and the final volume of each reaction was $20 \mu \mathrm{l}$. Two microliters of RNase/DNase-free sterile water was used as the non-template negative control. The thermocycle conditions were set as follows: initial denaturation at $95{ }^{\circ} \mathrm{C}$ for $30 \mathrm{~s}$ and 40 cycles of denaturation at $95{ }^{\circ} \mathrm{C}$ for $10 \mathrm{~s}$, annealing at $60{ }^{\circ} \mathrm{C}$ for $20 \mathrm{~s}$, and extension at $72{ }^{\circ} \mathrm{C}$ for $30 \mathrm{~s}$ with fluorescence detection. Furthermore, the melting curve analysis was performed at the end to identify non-specific amplification. All PCR protocols were performed in accordance with the Minimum Information for Publication of Quantitative Real-Time PCR Experiments (MIQE) guidelines (Bustin et al., 2009; Taylor \& Mrkusich, 2014). 


\section{Time kinetics of mRNA expression levels of selected cytokines of cPBMCs}

To evaluate the time kinetics of mRNA expression levels of selected cytokines in cPBMCs with ConA, the cytokine gene expression levels of cPBMCs with ConA $(0.5 \mu \mathrm{g} / \mathrm{ml})$ were determined by qRT-PCR $(N=4)$. Freshly-isolated cPBMCs were seeded in 96-well plates at a density of $5 \times 10^{5}$ cells/well and incubated for $0,4,8,12,16,20$ and $24 \mathrm{~h}$ of culture in a humidified atmosphere of $5 \% \mathrm{CO}_{2}$ at $37^{\circ} \mathrm{C}$. Then the $\mathrm{cPBMCs}$ were collected for subsequent mRNA extraction, complementary DNA (cDNA) synthesis, and qRT-PCR. The cPBMCs with $0 \mathrm{~h}$ incubation were used as control for the calculation of cytokine expression level by $\Delta \Delta \mathrm{CT}$ method. In addition, the geometric means of two housekeeping genes (HKGs), glyceraldehyde 3-phosphate dehydrogenase (GAPDH) and $\beta 2$-microglobulin (B2M), of each sample were determined and used to normalize the expression levels of target genes (Hellemans et al., 2007; Vandesompele et al., 2002).

\section{Effects of C-AgNP ${ }_{20}$ on mRNA expression levels of selected cytokines of cPBMCs}

The cPBMCs were seeded in 96-well plates at a density of $5 \times 10^{5}$ cells/well and exposed to sub-lethal doses of $\mathrm{C}-\mathrm{AgNP}_{20}$ with $0.5 \mu \mathrm{g} / \mathrm{ml} \mathrm{ConA}$ for 4 and $24 \mathrm{~h}$ of culture in a humidified atmosphere of $5 \% \mathrm{CO}_{2}$ at $37^{\circ} \mathrm{C}$. After incubation, the cPBMCs were collected for subsequent mRNA extraction, cDNA synthesis, and qRT-PCR. PBMCs with 4 and $24 \mathrm{~h}$ incubation without $\mathrm{C}-\mathrm{AgNP}_{20}$ treatment were used as control for the calculation of cytokine expression level by $\Delta \Delta \mathrm{CT}$ method. In addition, the geometric means of two HKGs, GAPDH and B2M, of each sample were determined and used to normalize the expression levels of target genes (Hellemans et al., 2007; Vandesompele et al., 2002). The experiment was independently repeated twice in duplicate $(N=12)$.

\section{Statistical analysis}

In all experiments, the results from duplicates were averaged. To compensate for individual differences, the results at different concentrations of $\mathrm{C}-\mathrm{AgNP}_{20}$ for each individual were calculated as percentages of the results of the control (exposed to $0 \mu \mathrm{g} / \mathrm{ml} \mathrm{C-AgNP} 20$ ). In addition, Th1/Th2 ratios at different concentrations of $\mathrm{C}-\mathrm{AgNP}_{20}$ were determined by the cytokine mRNA ratios of Th1 (IL-12 or INF- $\gamma$ ) and Th2 (IL-4) polarizing cytokines and then compared to the control. Our data were first checked by Shapiro-Wilk normality test and Brown-Forsythe test, and the results indicated that the assumptions of normality and/or equal variance were violated. Therefore, the Kruskal-Wallis Test (post hoc test: Dunn's multiple comparison test) was subsequently performed on the data. A $p$ value $<0.05$ was considered statistically significant, and the analysis was performed in Prism (GraphPad Software, La Jolla, CA, USA). All data were plotted on box-plot graphics. The bar in the middle of the box represented the second quartile (median), and the bottom and top of the box described the first and third quartiles. The whiskers showed that the 75th percentile plus 1.5 times IQR and 25th percentile minus 1.5 times IQR of all data, and any values that greater than these were defined as outliers and plotted as individual points. Asterisks above the boxplots indicated statistically significant differences compared to the control of each experiment. 


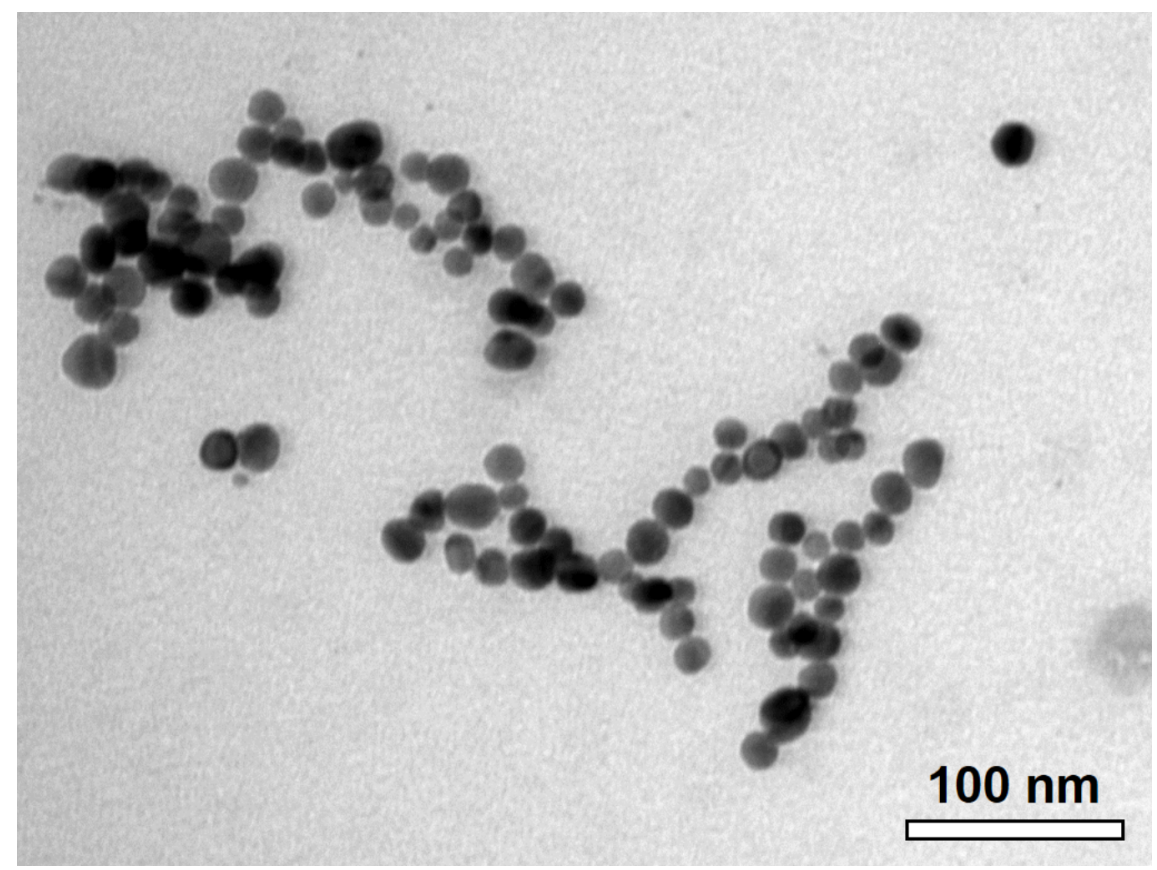

Figure 1 Characterization of C-AgNP $\mathbf{2 0}_{\mathbf{2 0}}$. Representative TEM image of C-AgNP 20 in complete RPMI1640.

Full-size DOI: 10.7717/peerj.5432/fig-1

\section{RESULTS}

\section{Characterization of $\mathrm{C}-\mathrm{AgNP}_{20}$}

The C-AgNP 20 in complete RPMI-1640 media were spherical and close to $20 \mathrm{~nm}$ in diameter (Fig. 1). The size distributions and zeta potentials of C-AgNP $20(100 \mathrm{or} 500 \mu \mathrm{g} / \mathrm{ml})$ in $2 \mathrm{mM}$ citrate buffer are illustrated in Table 1. The size distributions were $30.27 \pm 0.18$ $(100 \%)$ and $29.64 \pm 0.30(100 \%)$ for $\mathrm{C}^{-\mathrm{AgNP}_{20}}$ at 100 and $500 \mu \mathrm{g} / \mathrm{ml}$, respectively. The values of the zeta potential were $-38.97 \pm 1.33$ and $-44.2 \pm 1.35 \mathrm{mV}$ for $\mathrm{C}-\mathrm{AgNP}_{20}$ at 100 and $500 \mu \mathrm{g} / \mathrm{ml}$, respectively. Furthermore, the Poly-dispersity Indexes (PDIs) were $0.12 \pm$ 0.00 and $0.11 \pm 0.01$, indicating that the composition of $\mathrm{C}-\mathrm{AgNP}_{20}$ in the stock was in a single size mode without aggregates.

\section{Sub-lethal dose of $\mathrm{C}-\mathrm{AgNP}_{20}$ to the $\mathrm{cPBMCs}$ with or without ConA stimulation}

The treatment of $\mathrm{C}-\mathrm{AgNP}_{20}$ at $10 \mu \mathrm{g} / \mathrm{ml}$ significantly increased the ratios of late apoptotic/necrotic cells in cPBMCs with or without ConA stimulation. The ratios of early apoptotic and late apoptotic/necrotic cells of cPBMCs with different concentrations of $\mathrm{C}-\mathrm{AgNP}_{20}$ as compared to the control are presented in Fig. 2. After $24 \mathrm{~h}$ of $10 \mu \mathrm{g} / \mathrm{ml}$ $\mathrm{C}-\mathrm{AgNP}_{20}$ treatment, the ratios of late apoptotic/necrotic cells of $\mathrm{cPBMCs}$ significantly increased with (median \pm interquartile range (IQR): $3.55 \pm 3.42 ; p=0.0073$ ) or without ConA stimulation (median \pm IQR: $1.78 \pm 2.24 ; p=0.0103$ ). In contrast, no statistically significant increases in the ratios of apoptotic and late apoptotic/necrotic cells in cPBMCs were found after $24 \mathrm{~h}$ culture with 0.1 and $1.0 \mu \mathrm{g} / \mathrm{ml} \mathrm{C-AgNP}{ }_{20}$ treatments. Therefore, 0.1 

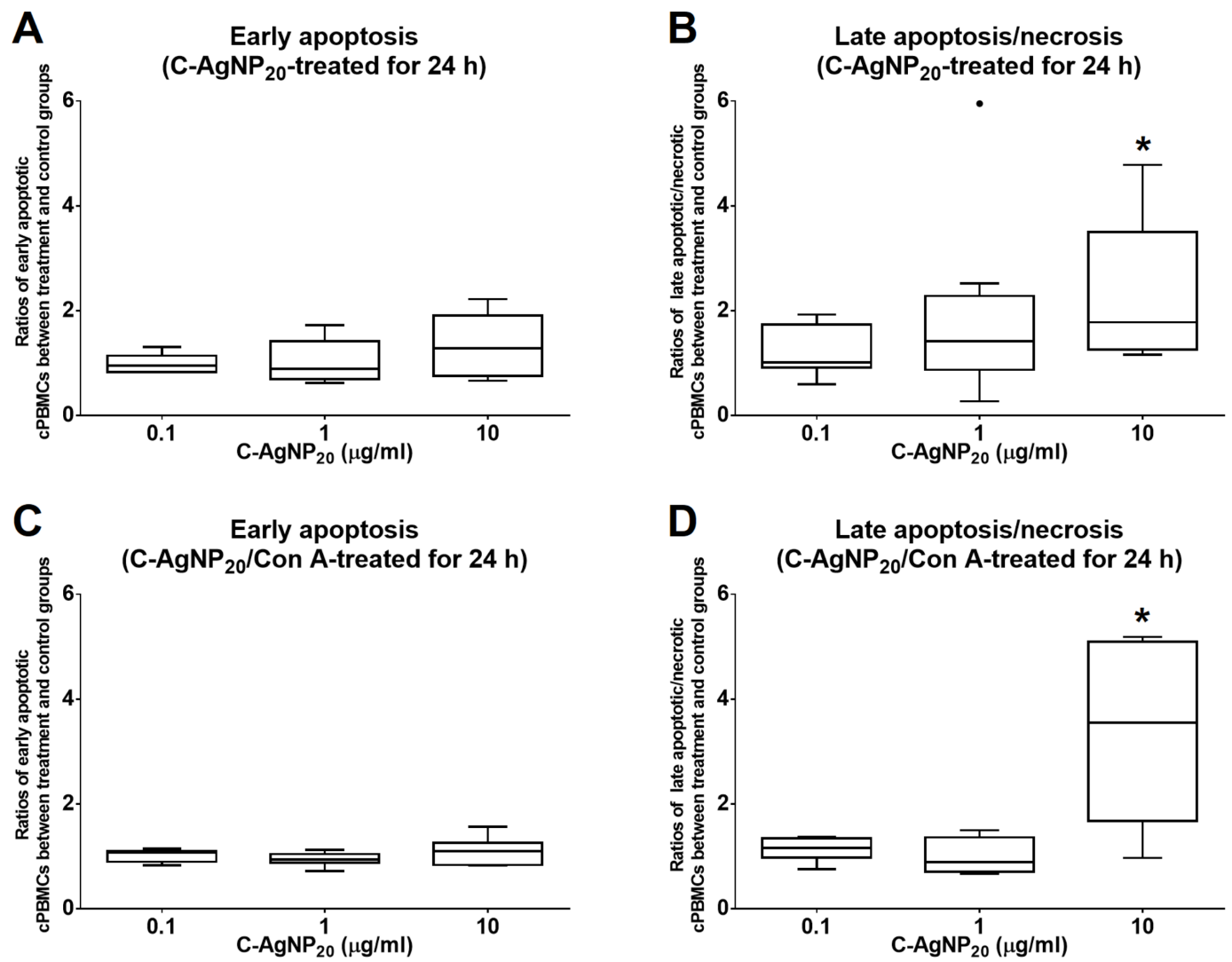

Figure 2 Cytotoxicity of C-AgNP ${ }_{20}$ on cPBMCs after $24 \mathrm{~h}$ of culture with or without ConA. (A) Ratio of apoptotic cPBMCs in percentage between treatment and control without ConA. (B) Ratio of late apoptotic/necrotic cPBMCs in percentage between treatment and control without ConA. (C) Ratio of apoptotic cPBMCs in percentage between treatment and control with ConA. (D) Ratio of late apoptotic/necrotic cPBMCs in percentage between treatment and control with ConA. The bar in the middle of the box represents the median, and the bottom and top of the box describe the first and third quartiles. The whiskers show the 75th percentile plus 1.5 times IQR and 25th percentile minus 1.5 times IQR of all data, and any values that are greater than these are defined as outliers and plotted as individual points. Asterisks indicate statistically significant differences from the control $(p<0.05$, Kruskal-Wallis Test).

Full-size DOI: 10.7717 /peerj.5432/fig-2

and $1.0 \mu \mathrm{g} / \mathrm{ml} \mathrm{C-AgNP} 20$ were defined as the sub-lethal doses for $\mathrm{CPBMCs}$ and used in the subsequent mRNA expression levels of selected cytokines in cPBMCs to C-AgNP 20 .

\section{qRT-PCR efficiency of each primer set}

Amplification efficiency (E) values for selected HKGs and cytokine genes, including GAPDH, B2M, IL-2, IL-4, IL-10, and IL-12, IFN- $\gamma$, and TNF- $\alpha$, ranged from 91.08 to $101.48 \%$ with $R^{2}>0.99$. The results are summarized in Table 2 .

\section{Time kinetics of mRNA expression levels of selected cytokines of cPBMCs with ConA stimulation}

The mRNA expression levels of IL-2 and TNF- $\alpha$ were significantly increased at $4 \mathrm{~h}$ of culture, gradually decreased from 8 to $20 \mathrm{~h}$ of culture, and then mildly but not significantly 
increased at $24 \mathrm{~h}$ of culture. The mRNA expression level of IFN- $\gamma$ was significantly increased at $4 \mathrm{~h}$ of culture, gradually decreased at 8 and $12 \mathrm{~h}$ of culture, and then increased from 16 to $24 \mathrm{~h}$ of culture. In addition, IL-4, IL-10, and IL-12 were significantly increased at $4 \mathrm{~h}$ of culture and gradually decreased over time. Therefore, the time points chosen for the following experiments were $4 \mathrm{~h}$ and $24 \mathrm{~h}$. All the results are illustrated in Fig. 3.

\section{Effects of C-AgNP ${ }_{20}$ on mRNA expression levels of selected cytokines in CPBMCs}

At $4 \mathrm{~h}$ of culture, the mRNA expression level of IL-10 was significantly decreased (median \pm

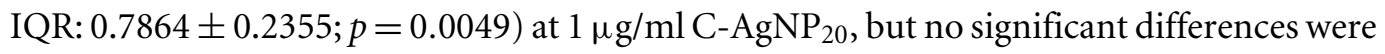
observed in the mRNA expression levels of other cytokine genes at 0.1 or $1 \mu \mathrm{g} / \mathrm{ml} \mathrm{C-AgNP} 20$ (Fig. 4). Following $24 \mathrm{~h}$ of culture with $1 \mu \mathrm{g} / \mathrm{ml} \mathrm{C-AgNP}{ }_{20}$, the mRNA expression levels of IL-2, IL-12, IFN- $\gamma$, and TNF- $\alpha$ were significantly decreased, but no significant difference was found in those of IL-4 and IL-10. Furthermore, the mRNA expression levels of IL-12 (median \pm IQR: $0.8337 \pm 0.2088 ; p=0.0339)$ and IFN $-\gamma$ (median \pm IQR: $0.7894 \pm 0.389$; $p=0.0164$ ) were also significantly decreased at $0.1 \mu \mathrm{g} / \mathrm{ml} \mathrm{C-AgNP}{ }_{20}$ (Fig. 4). The Th1/Th2 bias was defined by the ratios of Th 1 and Th2 polarizing cytokines. The IFN- $\gamma /$ IL- 4 ratio was significantly decreased following $24 \mathrm{~h}$ of culture with $1 \mu \mathrm{g} / \mathrm{ml} \mathrm{C}-\mathrm{AgNP}_{20}$, and the IL-12/IL-4 ratio was significantly decreased following 4 or $24 \mathrm{~h}$ of culture with 0.1 or $1 \mu \mathrm{g} / \mathrm{ml} \mathrm{C}-\mathrm{AgNP}_{20}$ treatments. Overall, the in vitro cytokine responses of cPBMCs with $\mathrm{C}-\mathrm{AgNP}_{20}$ treatments were biased toward Th2 cytokine response (Fig. 5).

\section{DISCUSSION}

Our data indicated that the concentration of $10 \mu \mathrm{g} / \mathrm{ml} \mathrm{C-AgNP}{ }_{20}$ was lethal dose for cPBMCs after $24 \mathrm{~h}$ of culture. Although previous studies of human PBMCs have used a variety of AgNPs (including different sizes and coatings), the lethal dose of AgNPs to human PBMCs is generally higher than $10 \mu \mathrm{g} / \mathrm{ml}$ (Ghosh et al., 2012; Greulich et al., 2011; Huang et al., 2016a; Orta-Garcia et al., 2015; Paino \& Zucolotto, 2015; Shin et al., 2007). Therefore, our data suggest that cPBMCs may be more vulnerable than human PBMCs to the cytotoxic effects of $\mathrm{C}-\mathrm{AgNP}_{20}$. However, previous studies have demonstrated that the toxicity and physicochemical characteristics of AgNPs are associated with their surface coating and size (Kim \& Ryu, 2013), and thus further investigation using the same AgNPs from the same manufacturer is necessary to compare the differences of susceptibility between cetaceans and humans. In addition, the negative effects of AgNPs with different sizes and coatings on the cPBMCs are also worth to be further studied.

It has been demonstrated that ConA (a selective T-cell mitogen) induces proliferative activity and gene expression of cytokines in bottlenose dolphins, but no information is available regarding the time course (Hofstetter et al., 2017; Segawa et al., 2013; Sitt et al., 2008). Previous studies on ConA-induced cytokine mRNA expression levels of cPBMCs only presented one or two time points (Segawa et al., 2013; Sitt et al., 2008). Sitt et al. (2008) quantified the ConA-induced cytokine mRNA expression levels of cPBMCs after $48 \mathrm{~h}$ of treatment, but the reason for choosing this time point was not explained. Their results showed that the mRNA expression levels of IL-2, IL-4, IL-12, and IFN- $\gamma$ in cPBMCs are 

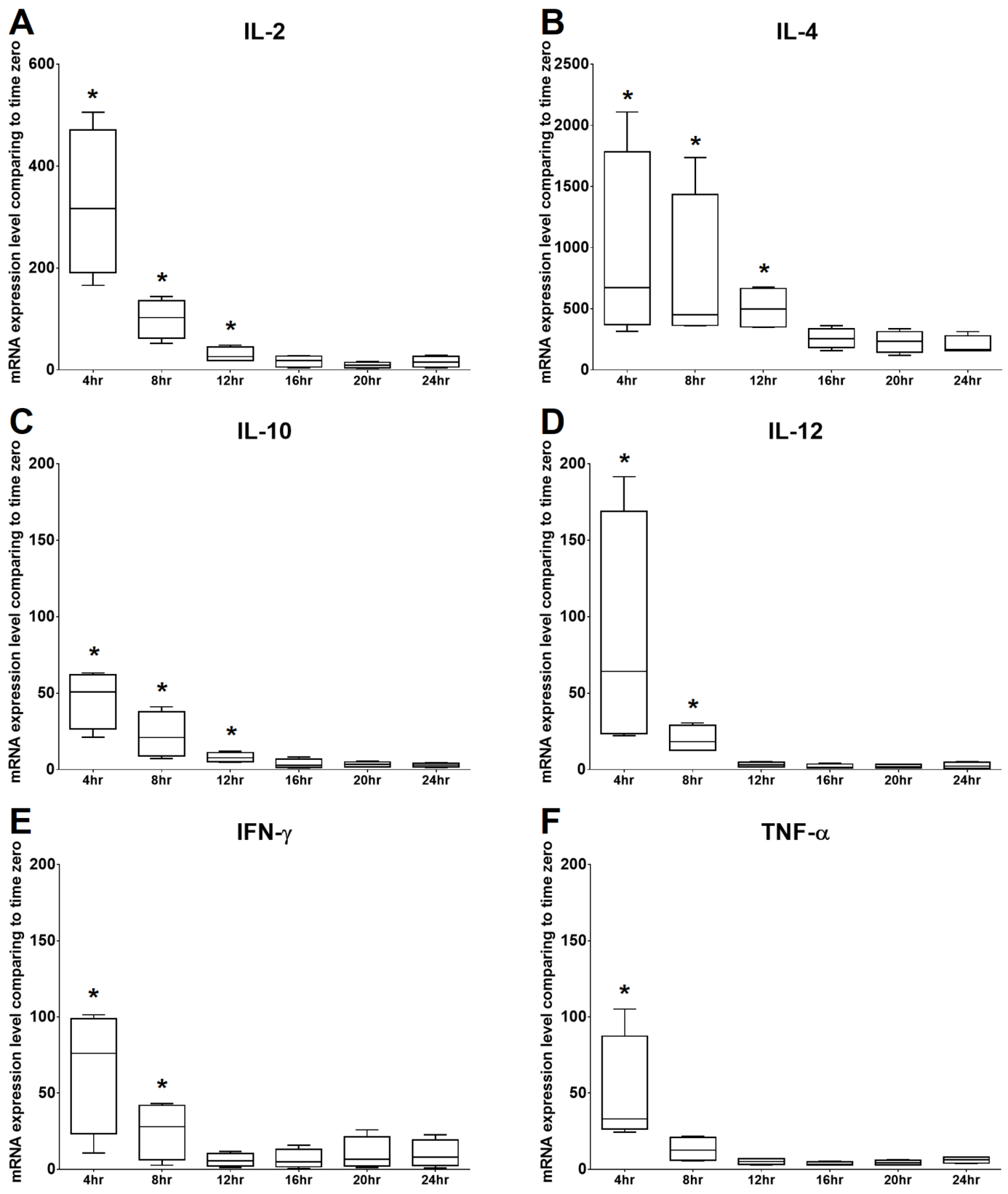

Figure 3 Time kinetics of mRNA expression levels of (A) IL-2, (B) IL-4, (C) IL-10, (D) IL-12, (E) IFN$\gamma$ and (F) TNF- $\alpha$ of cPBMCs with ConA. The bar in the middle of the box represents the median, and the bottom and top of the box describe the first and third quartiles. The whiskers show the 75th percentile plus 1.5 times IQR and 25th percentile minus 1.5 times IQR of all data, and any values that are greater than these are defined as outliers and plotted as individual points. Asterisks indicate statistically significant differences from the control ( $p<0.05$, Kruskal-Wallis Test).

Full-size DOI: 10.7717 /peerj.5432/fig-3

induced after $48 \mathrm{~h}$ of ConA stimulation, but those of IL-10 and TNF- $\alpha$ were not increased (Sitt et al., 2008). The other study demonstrated that the mRNA expression level of IL-10 in cPBMCs increased after $6 \mathrm{~h}$ of ConA stimulation (Segawa et al., 2013). Therefore, to apply appropriate time points for studying the effects of C-AgNP 20 on the cytokine mRNA 

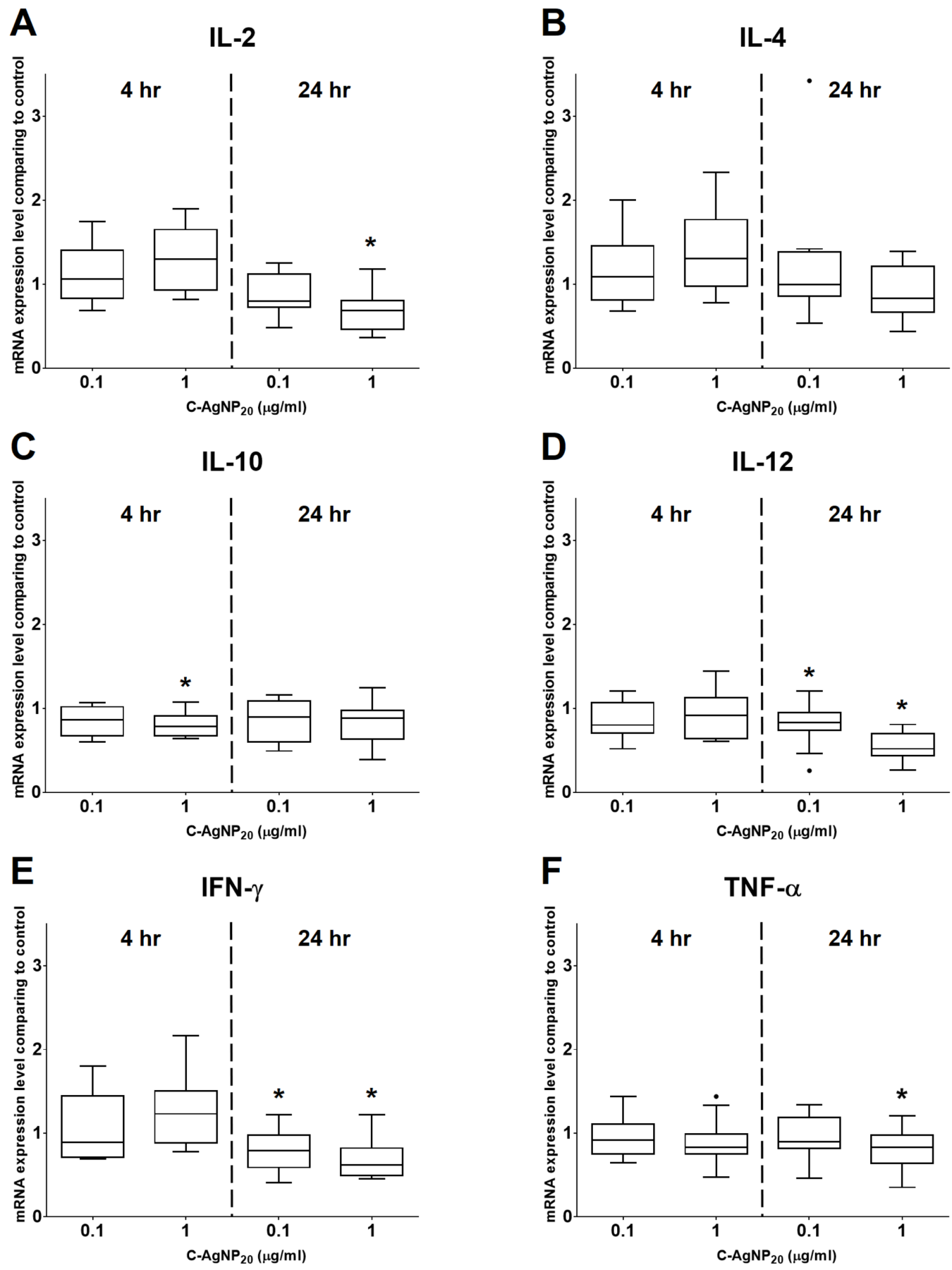

Figure 4 Effects of C-AgNP ${ }_{20}$ on mRNA expression levels of (A) IL-2, (B) IL-4, (C) IL-10, (D) IL-12, (E) IFN- $\gamma$ and (F) TNF- $\alpha$ of cPBMCs with ConA. The bar in the middle of the box represents the median, and the bottom and top of the box describe the first and third quartiles. The whiskers show the 75th percentile plus 1.5 times IQR and 25th percentile minus 1.5 times IQR of all data, and any values that are greater than these are defined as outliers and plotted as individual points. Asterisks indicate statistically significant differences from the control ( $p<0.05$, Kruskal-Wallis Test).

Full-size DOI: 10.7717/peerj.5432/fig-4 

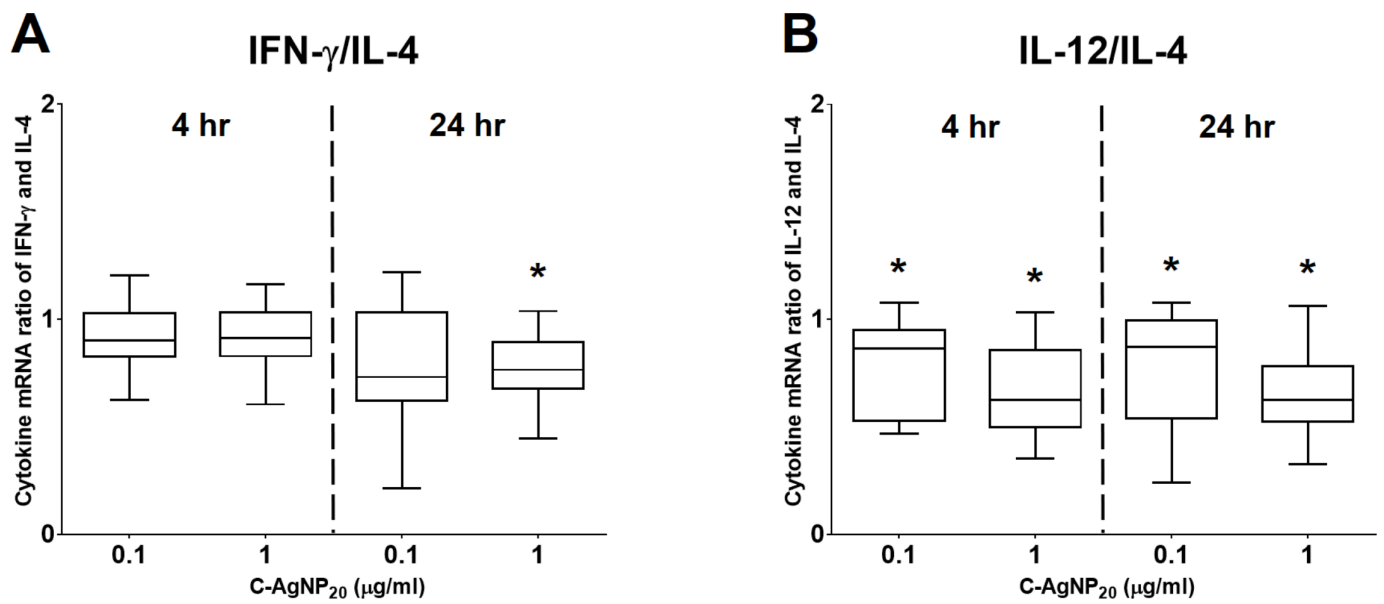

Figure 5 The ratios of Th1 and Th 2 polarizing cytokines at 4 and $24 \mathrm{~h}$ of culture. (A) Ratio of IFN- $\gamma$ and IL-4; (B) ratio of IL-12 and IL-4. The bar in the middle of the box represents the median, and the bottom and top of the box describe the first and third quartiles. The whiskers show the 75 th percentile plus 1.5 times IQR and 25th percentile minus 1.5 times IQR of all data, and any values that are greater than these are defined as outliers and plotted as individual points. Asterisks indicate statistically significant differences from the control ( $p<0.05$, Kruskal-Wallis Test).

Full-size DOI: 10.7717/peerj.5432/fig-5

expression levels of cPBMCs, the time kinetics (from 0 to $24 \mathrm{~h}$ ) of mRNA expression levels of IL-2, IL-4, IL-10, IL-12, IFN- $\gamma$ and TNF- $\alpha$ in cPBMCs with ConA stimulation were investigated. Our data indicated that the mRNA expression levels of all cytokine genes were significantly increased at $4 \mathrm{~h}$ of ConA stimulation and then gradually decreased with time. A longer incubation time was not possible in our study because the cell numbers of isolated cPBMCs were insufficient.

Previous studies have investigated the negative effects of AgNPs on cytokines in human PBMCs (Franco-Molina et al., 2016; Greulich et al., 2011; Shin et al., 2007). Uncoated AgNPs (1.5 nm; 1 to $2.5 \mathrm{~nm}$ in diameter) significantly inhibited the phytohemagglutinin (PHA)-induced IL-5, IFN- $\gamma$, and TNF- $\alpha$ production respectively at concentrations $\geq 10 \mu \mathrm{g} / \mathrm{ml}, \geq 3 \mu \mathrm{g} / \mathrm{ml}$, and $\geq 3 \mu \mathrm{g} / \mathrm{ml}$ in human PBMCs (Shin et al., 2007). It was reported that uncoated AgNPs (100 nm; 90 to $190 \mathrm{~nm}$ in diameter) at $0.0175 \mu \mathrm{g} / \mathrm{ml}$ can inhibit both PHA and ConA-induced IL-2 production in human PBMCs (Franco-Molina et al., 2016). Furthermore, polyvinylpyrrolidone (PVP)-coated AgNPs (75 $\pm 20 \mathrm{~nm}$ ) of five to $20 \mu \mathrm{g} / \mathrm{ml}$ significantly increased the generations of IL-6 and IL- 8 but significantly decreased the release of IL-1ra from human PBMCs, while PVP-coated AgNPs did not affect the productions of IL-2, IL-4 and TNF- $\alpha$ (Greulich et al., 2011). As mentioned above, the effects of AgNPs on cytokine production in human PBMCs remain inconclusive.

The mRNA expression levels of IL- 4 and IFN- $\gamma$ were mildly increased and that of IL-12 was seemingly unaffected at $4 \mathrm{~h}$ of C-AgNP 20 treatment. IL-4, as a polarizing Th2 cytokine, is mainly produced by $\mathrm{T}$ cells (especially the Th2 subset) and mast cells, and it promotes the differentiation of naïve $\mathrm{T}$ cells to Th2 cells, stimulates the growth and differentiation of B cells, and induces class switching to IgE, which may promote allergic responses (Owen et al., 2013; Tizard, 2013b). IFN- $\gamma$, as a polarizing Th1 cytokine and a 
key mediator of cell-mediated immune response, is produced by Th1 cells, cytotoxic $\mathrm{T}$ cells, and NK cells. The major functions of IFN- $\gamma$ are enhancement of Th1 differentiation, inhibition of Th2 differentiation, and activations of NK cells and macrophages (Owen et al., 2013; Tizard, 2013b). IL-12 is also a polarizing Th1 cytokine and is produced by dendritic cells, monocytes, macrophages and B cells. IL-12 induces differentiation of Th1 cells, increases IFN- $\gamma$ production by T cells and NK cells, and enhances NK and cytotoxic T cell activity (Owen et al., 2013; Tizard, 2013b). This mixed pattern of Th1 and Th2 cytokines may be indicative of a mixed Th1/Th2 cytokine response of cPBMCs at $4 \mathrm{~h}$ of C-AgNP 20 treatment. However, considering the significant decrease in the IL-12/IL-4 ratio, Th2 cytokine response is still predominant in $\mathrm{cPBMCs}$ following $4 \mathrm{~h}$ of $\mathrm{C}-\mathrm{AgNP}_{20}$ treatment. The mRNA expression levels of IL-12 and IFN- $\gamma$ were significantly decreased by 0.1 or one $\mu \mathrm{g} / \mathrm{ml} \mathrm{C-AgNP} 20$, and that of IL-4 was seemingly unaffected, in cPBMCs following $24 \mathrm{~h}$ of culture. The significantly decreased Th1/Th2 (i.e., IFN- $\gamma /$ IL-4 and IL-12/IL-4) ratios suggested that the immune response of $\mathrm{cPBMCs}$ following $24 \mathrm{~h}$ of $\mathrm{C}-\mathrm{AgNP}_{20}$ treatment is Th2 biased.

Furthermore, the mRNA expression level of TNF- $\alpha$ was significantly decreased by $1 \mu \mathrm{g} / \mathrm{ml} \mathrm{C-AgNP}{ }_{20}$ after $24 \mathrm{~h}$ of culture. TNF- $\alpha$ is a cytokine specifically useful to measure the inflammatory state of an animal and it is primarily produced by macrophages and both Th1 and Th2 cells in response to both acute and chronic conditions (Eberle et al., 2018). Previous studies have demonstrated that TNF- $\alpha$ is a contributing factor in the inflammatory response against infection of intracellular micropathogens such as Plasmodium spp., T. gondii, Leishmania major, and Trypanosoma spp. (Korner et al., 2010). Hence, our data indicate that $\mathrm{C}-\mathrm{AgNP}_{20}$ induced a $\mathrm{Th} 2$ biased immune response and suppressed the mRNA expression level of TNF- $\alpha$ in cPBMCs, which may weaken the cellular immune response and further impair the immunity against intracellular organisms and virus. Similar Th2 immune response was observed in other studies that evaluated the expression of cytokines in different cetacean tissues (Jaber et al., 2010). A variety of infections caused by intracellular pathogens in cetaceans have been reported and may be associated with the mass stranding events of cetaceans (Cvetnic et al., 2016; Domingo et al., 1990; Domingo et al., 1992; Dubey et al., 2007; Dubey et al., 2008; Mazzariol et al., 2016; Mazzariol et al., 2017). In addition, previous studies suggested that Ag contamination exists in all aspects of the marine ecosystem, and cetaceans may have been negatively affected by Ag contamination (Becker et al., 1995; Caceres-Saez et al., 2013; Chen et al., 2017; Dehn et al., 2006; Kunito et al., 2004; Li et al., 2018a; Mendez-Fernandez et al., 2014; Reed et al., 2015; Rosa et al., 2008; Seixas et al., 2009; Woshner et al., 2001). The direct correlation between the infection of intracellular pathogens and the severity of Ag contamination in cetaceans is worth studying.

Following $4 \mathrm{~h}$ of $1 \mu \mathrm{g} / \mathrm{ml} \mathrm{C-AgNP}{ }_{20}$ treatment, the mRNA expression level of IL-10 was significantly decreased and that of IL-2 was mildly increased. In other words, mRNA expression levels of IL-2 and IL-10 were respectively upregulated and downregulated by $\mathrm{C}-\mathrm{AgNP}_{20}$ in cPBMCs. Subsequently, the mRNA expression level of IL-2 was significantly decreased, and that of IL-10 seemingly unaffected, in cPBMCs following $24 \mathrm{~h}$ of treatment of $1 \mu \mathrm{g} / \mathrm{ml} \mathrm{C-AgNP} 20$. IL-2, which is produced by activated T cells, can stimulate proliferation 
and differentiation of T and B cells and activates NK cells (Owen et al., 2013; Tizard, 2013b). However, a growing body of evidence has indicated that IL-2 is crucial for the development and function of regulatory $\mathrm{T}$ cells (Treg cells), which secrete effector cytokines, such as IL-10, to control and modulate the immunity to self, neoplasia, microorganisms, and grafts (Owen et al., 2013; Pérol \& Piaggio, 2016). Considering the roles of IL-2 and IL-10 in immune tolerance, it is speculated that $\mathrm{C}-\mathrm{AgNP}_{20}$ may play a significant role in peripheral immune tolerance by regulating the balance between IL-2 and IL-10 (Pérol \& Piaggio, 2016; Veiopoulou et al., 2004).

The effect of $\mathrm{C}-\mathrm{AgNP}_{20}$ on the ConA-induced mRNA expression levels of the selected cytokines in cPBMCs is mainly inhibitory. A previous study found that PVP-AgNPs (10, $25,40,45$, and $110 \mathrm{~nm}$ in diameter) could bind to RNA polymerase, disturb the process of RNA transcription, and thus decreased the overall RNA synthesis in mouse erythroid progenitor cells (Wang et al., 2013). Although the down-regulation of mRNA expression levels may be associated with decreased RNA synthesis due to the direct interaction between $\mathrm{C}-\mathrm{AgNP}_{20}$ and RNA polymerase, it cannot fully explain the unaffected Th2 cytokines (IL-4 and IL-10) of cPBMCs in this study. On the other hand, the ConA-induced proliferative activity of cPBMCs is inhibited by 0.1 and $1.0 \mu \mathrm{g} / \mathrm{ml} \mathrm{C-AgNP}{ }_{20}$ (Li et al., 2018b), and this phenomenon may be associated with the decreased mRNA expression levels of IL-2, IL-12, IFN- $\gamma$, and TNF- $\alpha$ and/or a suppressive effect on DNA/RNA synthesis induced by ConA. Further investigation on the underlying mechanism of AgNPs in cetacean leukocytes is important to ascertain the negative health impact caused by AgNPs on cetaceans, and such investigation would improve the understanding of the potential hazards of AgNPs to environmental condition and human health.

Furthermore, although the biodistribution of AgNPs or Ag in cetaceans is still undetermined, previous in vivo studies of AgNPs by oral exposure in laboratory rats demonstrated that the Ag concentration in the liver is approximately 10 times higher than that in the blood or plasma (Lee et al., 2013; Loeschner et al., 2011; Van der Zande et al., 2012). Based on these animal models, it is presumed that the Ag concentrations in the blood of cetaceans may range from 0.01 to $72.6 \mu \mathrm{g} / \mathrm{ml}$ (Chen et al., 2017; Li et al., 2018a). Although previous studies have indicated that the status of AgNPs in the aquatic environment is complicated and variable (i.e., the concentrations of AgNPs and other Ag/Ag compounds are still undetermined in cetaceans)(Levard et al., 2012; Massarsky, Trudeau \& Moon, 2014), our data suggest that cetaceans may be negatively affected by AgNPs.

\section{CONCLUSIONS}

The present study has demonstrated: (1) the sublethal dose of $\mathrm{C}-\mathrm{AgNP}_{20}$ to $\mathrm{cPBMCs}$ $(\leq 1 \mu \mathrm{g} / \mathrm{ml})$, (2) the time kinetics of mRNA expression levels of selected cytokines in cPBMCs, and (3) the inhibitory effect of C-AgNP $20(0.1$ and $1 \mu \mathrm{g} / \mathrm{ml})$ on the mRNA expression levels of selected cytokines of cPBMCs with evidence of Th2 cytokine bias. Taken together, $\mathrm{C}-\mathrm{AgNP}_{20}$ may suppress the cellular immune response and thus inhibit the immunity against intracellular microorganisms in cetaceans. 


\section{ACKNOWLEDGEMENTS}

We thank the personnel of Farglory Ocean Park for blood sample collection and storage, the dolphins in Farglory Ocean Park for donating their blood, and Dr. Bang-Yeh Liou for blood sample transportation.

\section{ADDITIONAL INFORMATION AND DECLARATIONS}

\section{Funding}

The study was supported by the Ministry of Science \& Technology, Taiwan under Grant MOST 106-2313-B-002-054. The funders had no role in study design, data collection and analysis, decision to publish, or preparation of the manuscript.

\section{Grant Disclosures}

The following grant information was disclosed by the authors:

Ministry of Science \& Technology: MOST 106-2313-B-002-054.

\section{Competing Interests}

Chieh Lo is the veterinarian of Farglory Ocean Park, Hualien, Taiwan.

\section{Author Contributions}

- Wen-Ta Li conceived and designed the experiments, performed the experiments, analyzed the data, prepared figures and/or tables, authored or reviewed drafts of the paper, approved the final draft.

- Lei-Ya Wang performed the experiments, analyzed the data, prepared figures and/or tables, authored or reviewed drafts of the paper, approved the final draft.

- Hui-Wen Chang, Wei-Cheng Yang, Victor Fei Pang and Meng-Hsien Chen conceived and designed the experiments, contributed reagents/materials/analysis tools, authored or reviewed drafts of the paper, approved the final draft.

- Chieh Lo performed the experiments, authored or reviewed drafts of the paper, approved the final draft, collected the blood samples from captive dolphins.

- Chian-Ren Jeng conceived and designed the experiments, analyzed the data, contributed reagents/materials/analysis tools, authored or reviewed drafts of the paper, approved the final draft.

\section{Animal Ethics}

The following information was supplied relating to ethical approvals (i.e., approving body and any reference numbers):

All procedures involving animals were conducted in accordance with international guidelines, and the protocol had been reviewed and approved by the Council of Agriculture of Taiwan (Approval number 1051700175).

\section{Data Availability}

The following information was supplied regarding data availability:

The raw data are provided in the Supplemental Files. 


\section{Supplemental Information}

Supplemental information for this article can be found online at http://dx.doi.org/10.7717/ peerj.5432\#supplemental-information.

\section{REFERENCES}

Becker P, Mackey E, Demiralp R, Suydam R, Early G, Koster B, Wise S. 1995. Relationship of silver with selenium and mercury in the liver of two species of toothed whales (odontocetes). Marine Pollution Bulletin 30:262-271

DOI 10.1016/0025-326X(94)00176-A.

Beineke A, Siebert U, Van Elk N, Baumgartner W. 2004. Development of a lymphocytetransformation-assay for peripheral blood lymphocytes of the harbor porpoise and detection of cytokines using the reverse-transcription polymerase chain reaction. Immunology and Immunopathology 98:59-68 DOI 10.1016/j.vetimm.2003.10.002.

Beineke A, Siebert U, Wohlsein P, Baumgartner W. 2010. Immunology of whales and dolphins. Veterinary Immunology and Immunopathology 133:81-94 DOI 10.1016/j.vetimm.2009.06.019.

Bossart GD, Romano TA, Peden-Adams MM, Rice CD, Fair PA, Goldstein JD, Kilpatrick D, Cammen K, Reif JS. 2008. Hematological, biochemical, and immunological findings in Atlantic bottlenose dolphins (Tursiops truncatus) with orogenital papillomas. Aquatic Mammals 34:166-177 DOI 10.1578/AM.34.2.2008.166.

Buffet PE, Zalouk-Vergnoux A, Chatel A, Berthet B, Metais I, Perrein-Ettajani H, Poirier L, Luna-Acosta A, Thomas-Guyon H, Risso-de Faverney C, Guibbolini M, Gilliland D, Valsami-Jones E, Mouneyrac C. 2014. A marine mesocosm study on the environmental fate of silver nanoparticles and toxicity effects on two endobenthic species: the ragworm Hediste diversicolor and the bivalve mollusc Scrobicularia plana. Science of the Total Environment 470-471:1151-1159 DOI 10.1016/j.scitotenv.2013.10.114.

Bustin SA, Benes V, Garson JA, Hellemans J, Huggett J, Kubista M, Mueller R, Nolan T, Pfaffl MW, Shipley GL, Vandesompele J, Wittwer CT. 2009. The MIQE guidelines: minimum information for publication of quantitative real-time PCR experiments. Clinical Chemistry 55:611-622 DOI 10.1373/clinchem.2008.112797.

Caceres-Saez I, Ribeiro Guevara S, Dellabianca NA, Goodall RN, Cappozzo HL. 2013. Heavy metals and essential elements in Commerson's dolphins (Cephalorhynchus c. commersonii) from the southwestern South Atlantic Ocean. Environmental Monitoring and Assessment 185:5375-5386 DOI 10.1007/s10661-012-2952-y.

Chen IH, Chou LS, Chou SJ, Wang JH, Stott J, Blanchard M, Jen IF, Yang WC. 2015. Selection of suitable reference genes for normalization of quantitative RT-PCR in peripheral blood samples of bottlenose dolphins (Tursiops truncatus). Scientific Reports 5:15425 DOI 10.1038/srep15425.

Chen MH, Zhuang MF, Chou LS, Liu JY, Shih CC, Chen CY. 2017. Tissue concentrations of four Taiwanese toothed cetaceans indicating the silver and cadmium 
pollution in the western Pacific Ocean. Marine Pollution Bulletin 124:993-1000

DOI 10.1016/j.marpolbul.2017.03.028.

Cvetnic Z, Duvnjak S, Duras M, Gomercic T, Reil I, Zdelar-Tuk M, Spicic S. 2016. Evidence of Brucella strain ST27 in bottlenose dolphin (Tursiops truncatus) in Europe. Microbiology 196:93-97 DOI 10.1016/j.vetmic.2016.10.013.

Dehn LA, Follmann EH, Thomas DL, Sheffield GG, Rosa C, Duffy LK, O'Hara TM. 2006. Trophic relationships in an Arctic food web and implications for trace metal transfer. Science of the Total Environment 362:103-123

DOI 10.1016/j.scitotenv.2005.11.012.

Desforges JP, Sonne C, Levin M, Siebert U, De Guise S, Dietz R. 2016. Immunotoxic effects of environmental pollutants in marine mammals. Environment International 86:126-139 DOI 10.1016/j.envint.2015.10.007.

Domingo M, Ferrer L, Pumarola M, Marco A, Plana J, Kennedy S, McAliskey M, Rima BK. 1990. Morbillivirus in dolphins. Nature 348:21 DOI 10.1038/348021a0.

Domingo M, Visa J, Pumarola M, Marco AJ, Ferrer L, Rabanal R, Kennedy S. 1992. Pathologic and immunocytochemical studies of morbillivirus infection in striped dolphins (Stenella coeruleoalba). Veterinary Pathology 29:1-10 DOI 10.1177/030098589202900101.

Dubey JP, Fair PA, Sundar N, Velmurugan G, Kwok OC, McFee WE, Majumdar D, Su C. 2008. Isolation of Toxoplasma gondii from bottlenose dolphins (Tursiops truncatus). Journal of Parasitology 94:821-823 DOI 10.1645/GE-1444.1.

Dubey JP, Morales JA, Sundar N, Velmurugan GV, Gonzalez-Barrientos CR, Hernandez-Mora G, Su C. 2007. Isolation and genetic characterization of Toxoplasma gondii from striped dolphin (Stenella coeruleoalba) from Costa Rica. Journal of Parasitology 93:710-711 DOI 10.1645/GE-1120R.1.

Eberle KC, Venn-Watson SK, Jensen ED, LaBresh J, Sullivan Y, Kakach L, Sacco RE. 2018. Development and testing of species-specific ELISA assays to measure IFNgamma and TNF-alpha in bottlenose dolphins (Tursiops truncatus). PLOS ONE 13:e0190786 DOI 10.1371/journal.pone.0190786.

Espinosa-Cristobal LF, Martinez-Castanon GA, Loyola-Rodriguez JP, Patino-Marin N, Reyes-Macias JF, Vargas-Morales JM, Ruiz F. 2013. Toxicity, distribution, and accumulation of silver nanoparticles in Wistar rats. Journal of Nanoparticle Research 15:Article 1702 DOI 10.1007/S11051-013-1702-6.

Farre M, Gajda-Schrantz K, Kantiani L, Barcelo D. 2009. Ecotoxicity and analysis of nanomaterials in the aquatic environment. Analytical and Bioanalytical Chemistry 393:81-95 DOI 10.1007/s00216-008-2458-1.

Franco-Molina MA, Mendoza-Gamboa E, Zarate-Triviño DG, Coronado-Cerda EE, Alcocer-González JM, Resendez-Pérez D, Rodríguez-Salazar MC, RiveraMorales LG, Tamez-Guerra R, Rodríguez-Padilla C. 2016. In vitro evaluation of colloidal silver on immune function: Antilymphoproliferative activity. Journal of Nanomaterials 2017:1-12 DOI 10.1155/2016/4176212.

Gagne F, Auclair J, Fortier M, Bruneau A, Fournier M, Turcotte P, Pilote M, Gagnon C. 2013. Bioavailability and immunotoxicity of silver nanoparticles to the freshwater 
mussel Elliptio complanata. Journal of Toxicology and Environmental Health, Part A 76:767-777 DOI 10.1080/15287394.2013.818602.

Gambardella C, Costa E, Piazza V, Fabbrocini A, Magi E, Faimali M, Garaventa F. 2015. Effect of silver nanoparticles on marine organisms belonging to different trophic levels. Marine Environmental Research 111:41-49 DOI 10.1016/j.marenvres.2015.06.001.

Ghosh MJM, Manivannan J, Sinha S, Chakraborty A, Mallick SK, Bandyopadhyay M, Mukherjee A. 2012. In vitro and in vivo genotoxicity of silver nanoparticles. Mutation Research 749:60-69 DOI 10.1016/j.mrgentox.2012.08.007.

Greulich C, Diendorf J, Gessmann J, Simon T, Habijan T, Eggeler G, Schildhauer TA, Epple M, Koller M. 2011. Cell type-specific responses of peripheral blood mononuclear cells to silver nanoparticles. Acta Biomaterialia 7:3505-3514 DOI 10.1016/j.actbio.2011.05.030.

Hellemans J, Mortier G, De Paepe A, Speleman F, Vandesompele J. 2007. qBase relative quantification framework and software for management and automated analysis of real-time quantitative PCR data. Genome Biology 8:Article R19 DOI 10.1186/gb-2007-8-2-r19.

Hofstetter AR, Eberle KC, Venn-Watson SK, Jensen ED, Porter TJ, Waters TE, Sacco RE. 2017. Monitoring bottlenose dolphin leukocyte cytokine mRNA responsiveness by qPCR. PLOS ONE 12:e189437 DOI 10.1371/journal.pone.0189437.

Huang H, Lai W, Cui M, Liang L, Lin Y, Fang Q, Liu Y, Xie L. 2016a. An evaluation of blood compatibility of silver nanoparticles. Scientific Reports 6:25518 DOI 10.1038/srep25518.

Huang J, Cheng J, Yi J. 2016b. Impact of silver nanoparticles on marine diatom Skeletonema costatum. Journal of Applied Toxicology 36:1343-1354 DOI 10.1002/jat.3325.

Jaber JR, Perez J, Zafra R, Herraez P, Rodriguez F, Arbelo M, De los Monteros AE, Fernandez A. 2010. Cross-reactivity of anti-human, anti-porcine and anti-bovine cytokine antibodies with cetacean tissues. Journal of Comparative Pathology 143:45-51 DOI 10.1016/j.jcpa.2010.01.001.

Kidd. 2003. Th1/Th2 balance: the hypothesis, its limitations, and implications for health and disease. Alternative Medicine Review 8:223-246.

Kim S, Ryu DY. 2013. Silver nanoparticle-induced oxidative stress, genotoxicity and apoptosis in cultured cells and animal tissues. Journal of Applied Toxicology 33:78-89 DOI 10.1002/jat.2792.

Korner H, McMorran B, Schluter D, Fromm. 2010. The role of TNF in parasitic diseases: still more questions than answers. International Journal for Parasitology 40:879-888 DOI 10.1016/j.ijpara.2010.03.011.

Kunito T, Nakamura S, Ikemoto T, Anan Y, Kubota R, Tanabe S, Rosas FC, Fillmann G, Readman JW. 2004. Concentration and subcellular distribution of trace elements in liver of small cetaceans incidentally caught along the Brazilian coast. Marine Pollution Bulletin 49:574-587 DOI 10.1016/j.marpolbul.2004.03.009.

Lee JH, Kim YS, Song KS, Ryu HR, Sung JH, Park JD, Park HM, Song NW, Shin BS, Marshak D, Ahn K, Lee JE, Yu IJ. 2013. Biopersistence of silver nanoparticles 
in tissues from Sprague-Dawley rats. Particle and Fibre Toxicology 10:Article 36 DOI 10.1186/1743-8977-10-36.

Levard C, Hotze EM, Lowry GV, Brown Jr GE. 2012. Environmental transformations of silver nanoparticles: impact on stability and toxicity. Environmental Science and Technology 46:6900-6914 DOI 10.1021/es2037405.

Li WT, Chang HW, Chen MH, Chiou HY, Liou BY, Pang VF, Yang WC, Jeng CR. 2018a. Investigation of silver (Ag) deposition in tissues from stranded cetaceans by autometallography (AMG). Environmental Pollution 235:534-545 DOI 10.1016/j.envpol.2018.01.010.

Li WT, Chang HW, Yang WC, Lo C, Wang LY, Pang VF, Chen MH, Jeng CR. 2018b. Immunotoxicity of Silver Nanoparticles (AgNPs) on the Leukocytes of Common Bottlenose Dolphins (Tursiops truncatus). Scientific Reports 8:5593 DOI 10.1038/s41598-018-23737-0.

Loeschner K, Hadrup N, Qvortrup K, Larsen A, Gao X, Vogel U, Mortensen A, Lam HR, Larsen EH. 2011. Distribution of silver in rats following 28 days of repeated oral exposure to silver nanoparticles or silver acetate. Particle and Fibre Toxicology 8:Article 18 DOI 10.1186/1743-8977-8-18.

Massarsky A, Trudeau VL, Moon TW. 2014. Predicting the environmental impact of nanosilver. Environmental Toxicology and Pharmacology 38:861-873 DOI 10.1016/j.etap.2014.10.006.

Mazzariol S, Centelleghe C, Beffagna G, Povinelli M, Terracciano G, Cocumelli C, Pintore A, Denurra D, Casalone C, Pautasso A, Di Francesco CE, Di Guardo G. 2016. Mediterranean fin whales (Balaenoptera physalus) threatened by dolphin morbillivirus. Infectious Diseases 22:302-305 DOI 10.3201/eid2202.15-0882.

Mazzariol S, Centelleghe C, Di Provvido A, Di Renzo L, Cardeti G, Cersini A, Fichi G, Petrella A, Di Francesco CE, Mignone W, Casalone C, Di Guardo G. 2017. Dolphin morbillivirus associated with a mass stranding of sperm whales, Italy. Emerging Infectious Diseases 23:144-146 DOI 10.3201/eid2301.160239.

Mendez-Fernandez P, Webster L, Chouvelon T, Bustamante P, Ferreira M, Gonzalez AF, Lopez A, Moffat CF, Pierce GJ, Read FL, Russell M, Santos MB, Spitz J, Vingada JV, Caurant F. 2014. An assessment of contaminant concentrations in toothed whale species of the NW Iberian Peninsula: part II. Trace element concentrations. Science of the Total Environment 484:206-217 DOI 10.1016/j.scitotenv.2014.03.001.

Orta-Garcia ST, Plascencia-Villa G, Ochoa-Martinez AC, Ruiz-Vera T, Perez-Vazquez FJ, Velazquez-Salazar JJ, Yacaman MJ, Navarro-Contreras HR, Perez-Maldonado IN. 2015. Analysis of cytotoxic effects of silver nanoclusters on human peripheral blood mononuclear cells 'in vitro'. Journal of Applied Toxicology 35:1189-1199 DOI 10.1002/jat.3190.

Owen JA, Punt J, Stranford SA, Jones PP, Kuby J. 2013. Kuby immunology. New York: W.H. Freeman.

Paino IM, Zucolotto V. 2015. Poly(vinyl alcohol)-coated silver nanoparticles: activation of neutrophils and nanotoxicology effects in human hepatocarcinoma 
and mononuclear cells. Environmental Toxicology and Pharmacology 39:614-621

DOI 10.1016/j.etap.2014.12.012.

Pérol L, Piaggio E. 2016. New molecular and cellular mechanisms of tolerance: tolerogenic actions of IL-2. In: Cuturi MC, Anegon I, eds. Suppression and regulation of immune responses: methods and protocols. Vol. II. New York: Humana Press, 11-28.

Poirier M, Simard JC, Antoine F, Girard D. 2014. Interaction between silver nanoparticles of $20 \mathrm{~nm}\left(\mathrm{AgNP}_{20}\right)$ and human neutrophils: induction of apoptosis and inhibition of de novo protein synthesis by $\mathrm{AgNP}_{20}$ aggregates. Journal of Applied Toxicology 34:404-412 DOI 10.1002/jat.2956.

Poirier M, Simard JC, Girard D. 2016. Silver nanoparticles of $70 \mathrm{~nm}$ and $20 \mathrm{~nm}$ affect differently the biology of human neutrophils. Journal of Immunotoxicology 13:375-385 DOI 10.3109/1547691X.2015.1106622.

Raphael I, Nalawade S, Eagar TN, Forsthuber TG. 2015. T cell subsets and their signature cytokines in autoimmune and inflammatory diseases. Cytokine 74:5-17 DOI 10.1016/j.cyto.2014.09.011.

Reed LA, McFee WE, Pennington PL, Wirth EF, Fulton MH. 2015. A survey of trace element distribution in tissues of the dwarf sperm whale (Kogia sima) stranded along the South Carolina coast from 1990-2011. Marine Pollution Bulletin 100:501-506 DOI 10.1016/j.marpolbul.2015.09.005.

Rosa C, Blake JE, Bratton GR, Dehn LA, Gray MJ, O'Hara TM. 2008. Heavy metal and mineral concentrations and their relationship to histopathological findings in the bowhead whale (Balaena mysticetus). Science of the Total Environment 399:165-178 DOI 10.1016/j.scitotenv.2008.01.062.

Sardari RRR, Zarchi SR, Talebi A, Nasri S, Imani S, Khoradmehr A, Sheshde SAR. 2012. Toxicological effects of silver nanoparticles in rats. African Journal of Microbiology Research 6:5587-5593 DOI 10.5897/Ajmr11.1070.

Segawa T, Karatani N, Itou T, Suzuki M, Sakai T. 2013. Cloning and characterization of bottlenose dolphin (Tursiops truncatus) interleukin-10. Immunology and Immunopathology 154:62-67 DOI 10.1016/j.vetimm.2013.04.009.

Seixas TG, Kehrig HA, Di Beneditto AP, Souza CM, Malm O, Moreira I. 2009. Essential ( $\mathrm{Se}, \mathrm{Cu}$ ) and non-essential ( $\mathrm{Ag}, \mathrm{Hg}, \mathrm{Cd}$ ) elements: what are their relationships in liver of Sotalia guianensis (Cetacea, Delphinidae)? Marine Pollution Bulletin 58:629-634 DOI 10.1016/j.marpolbul.2008.12.005.

Shahare B, Yashpal M. 2013. Toxic effects of repeated oral exposure of silver nanoparticles on small intestine mucosa of mice. Toxicology Mechanisms and Methods 23:161-167 DOI 10.3109/15376516.2013.764950.

Shin SH, Ye MK, Kim HS, Kang HS. 2007. The effects of nano-silver on the proliferation and cytokine expression by peripheral blood mononuclear cells. International Immunopharmacology 7:1813-1818 DOI 10.1016/j.intimp.2007.08.025.

Sitt T, Bowen L, Blanchard MT, Smith BR, Gershwin LJ, Byrne BA, Stott JL. 2008. Quantitation of leukocyte gene expression in cetaceans. Developmental and Comparative Immunology 32:1253-1259 DOI 10.1016/j.dci.2008.05.001. 
Soares T, Ribeiro D, Proenca C, Chiste RC, Fernandes E, Freitas M. 2016. Sizedependent cytotoxicity of silver nanoparticles in human neutrophils assessed by multiple analytical approaches. Life Sciences 145:247-254 DOI 10.1016/j.lfs.2015.12.046.

Svec D, Tichopad A, Novosadova V, Pfaffl MW, Kubista M. 2015. How good is a PCR efficiency estimate: recommendations for precise and robust qPCR efficiency assessments. Biomolecular Detection and Quantification 3:9-16 DOI 10.1016/j.bdq.2015.01.005.

Taylor SC, Mrkusich EM. 2014. The state of RT-quantitative PCR: firsthand observations of implementation of minimum information for the publication of quantitative realtime PCR experiments (MIQE). Journal of Molecular Microbiology and Biotechnology 24:46-52 DOI 10.1159/000356189.

Thummabancha K, Onparn N, Srisapoome. 2016. Analysis of hematologic alterations, immune responses and metallothionein gene expression in Nile tilapia (Oreochromis niloticus) exposed to silver nanoparticles. Journal of Immunotoxicology 3:909-917 DOI 10.1080/1547691X.2016.1242673.

Tizard IR. 2013a. Cell signaling: cytokines and their receptors. In: Tizard IR, ed. Veterinary immunology. Ninth Edition. St. Louis: Saunders, 75-83.

Tizard IR. 2013b. Helper T cells and their response to antigen. In: Tizard IR, ed. Veterinary immunology. Ninth Edition. St. Louis: Saunders, 137-149.

Van der Zande M, Vandebriel RJ, Van Doren E, Kramer E, Herrera Rivera Z, SerranoRojero CS, Gremmer ER, Mast J, Peters RJ, Hollman PC, Hendriksen PJ, Marvin HJ, Peijnenburg AA, Bouwmeester H. 2012. Distribution, elimination, and toxicity of silver nanoparticles and silver ions in rats after 28-day oral exposure. ACS Nano 6:7427-7442 DOI 10.1021/nn302649p.

Vandesompele J, De Preter K, Pattyn F, Poppe B, Van Roy N, De Paepe A, Speleman F. 2002. Accurate normalization of real-time quantitative RT-PCR data by geometric averaging of multiple internal control genes. Genome Biology 3:research0034.1-research0034.11.

Veiopoulou C, Kogopoulou O, Tzakos E, Mavrothalassitis G, Mitsias D, Karafoulidou A, Paliogianni F, Moutsopoulos HM, Thyphronitis G. 2004. IL-2 and IL-10 production by human CD4+T cells is differentially regulated by $\mathrm{p} 38$ : mode of stimulation-dependent regulation of IL-2. Neuroimmunomodulation 11:199-208 DOI 10.1159/000078437.

Walters CR, Pool EJ, Somerset VS. 2014. Ecotoxicity of silver nanomaterials in the aquatic environment: a review of literature and gaps in nano-toxicological research. Journal of Environmental Science and Health. Part A, Toxic/hazardous Substances and Environmental Engineering 49:1588-1601 DOI 10.1080/10934529.2014.938536.

Wang H, Ho KT, Scheckel KG, Wu F, Cantwell MG, Katz DR, Horowitz DB, Boothman WS, Burgess RM. 2014. Toxicity, bioaccumulation, and biotransformation of silver nanoparticles in marine organisms. Environmental Science and Technology 48:13711-13717 DOI 10.1021/es502976y. 
Wang Z, Liu S, Ma J, Qu G, Wang X, Yu S, He J, Liu J, Xia T, Jiang GB. 2013. Silver nanoparticles induced RNA polymerase-silver binding and RNA transcription inhibition in erythroid progenitor cells. ACS Nano 7:4171-4186 DOI 10.1021/nn400594s.

Woshner VM, O'Hara TM, Bratton GR, Suydam RS, Beasley VR. 2001. Concentrations and interactions of selected essential and non-essential elements in bowhead and beluga whales of arctic Alaska. Journal of Wildlife Diseases 37:693-710 DOI 10.7589/0090-3558-37.4.693. 